\title{
Thematic development of declarations on Sustainability in Higher Education
}

\author{
Grindsted, Thomas Skou; Holm, Tove
}

Published in:

Environmental Economics

Publication date:

2012

Document Version

Publisher's PDF, also known as Version of record

Citation for published version (APA):

Grindsted, T. S., \& Holm, T. (2012). Thematic development of declarations on Sustainability in Higher Education. Environmental Economics, 3(1), 32.

\section{General rights}

Copyright and moral rights for the publications made accessible in the public portal are retained by the authors and/or other copyright owners and it is a condition of accessing publications that users recognise and abide by the legal requirements associated with these rights.

- Users may download and print one copy of any publication from the public portal for the purpose of private study or research.

- You may not further distribute the material or use it for any profit-making activity or commercial gain.

- You may freely distribute the URL identifying the publication in the public portal.

\section{Take down policy}

If you believe that this document breaches copyright please contact rucforsk@kb.dk providing details, and we will remove access to the work immediately and investigate your claim. 
Thomas S. Grindsted (Denmark), Tove Holm (Finland)

\title{
Thematic development of declarations on Sustainability in Higher Education
}

\begin{abstract}
Declarations on Sustainability in Higher Education (SHE) have grown in number and significance over the last decade. SHE declarations can be viewed as a piece of non binding international regulation that shapes universities' pioneering role in ensuring sustainable development.

Examination of the international SHE literature reveals no study that deals specifically with the interaction between declarations developed by the university sector and declarations developed by governmental and intergovernmental institutions. An analysis of this type can give us important insights in what themes these parties think should be given top priority in order to develop a sustainable society. Hence, the article addresses the following issues: (1) a thematic analysis of the relation between declarations developed by the university sector and those developed by governmental and intergovernmental institutions; (2) an analysis of themes the two types of declarations might have in common; and if so (3) an analysis of how they have developed during the past decade. The article finds four new themes that previous research has not identified, and shows how the valuation of nature is under reconfiguration in higher education policy.
\end{abstract}

Keywords: Sustainability in Higher Education declarations. JEL Classification: Q56.

\section{Introduction}

Since the turn of the millennium the number of SHE declarations has increased significantly, and the number of universities that have signed such declarations has also risen (Waas et al., 2009). Although SHE declarations are so called "soft laws" (declarations of intent) they are to be considered as the most concrete document that has been developed so far in the ongoing interactive process between university leaders, university institutions and governmental/inter-governmental institutions (principals and signatories) (Grindsted, 2011). Thus, a SHE declaration is to be seen as a joint agenda setting position paper which "frames" how universities articulate their function and role (Wright, 2002). Previous research has investigated the SHE declarations from various angels. Wright (2002, 2004) identifies eight themes and suggests that they are constant over time and Waas et al. (2009) investigates sustainable research in SHE declarations. Bekessy et al. (2007), Alshuwaikhat and Abubaka (2008) among others, show how the signing of declarations not necessarily translates into implementation. Clarke and Kouri (2009), Lozano et al. (2011), find that declarations have had an impact on university management, and Zilahy (2009) has analyzed the role of academia in regional sustainable development. The development of SHE declarations have made a number of researchers, e.g. Corcoran et al. (2002), Calder and Clugston (2003), Wright and Pullen (2007), Harpe and Thomas (2009), Mcmillin and Dyball (2009), suggest that SHE declarations and conferences have had the

(C) Thomas S. Grindsted, Tove Holm, 2012.

I would like to thank Henrik Toft Jensen, Associate Professor at ENSPAC, Department of Environmental, Social and Spatial Change, Roskilde University, Denmark; and Annette Marie Grindsted, Associate Professor, Institute of Language and Communication, University of Southern Denmark. definition power and thus a decisive influence on what sustainability means in higher education (Cortese, 1999). Hence, these researchers find an emerging international consensus on the university's role in relation to sustainability and show how the ecological modernization discourse is emphasized in research and education policy discussions about the university's role and function in society (Grindsted, 2011). However, an examination of the international SHE literature reveals no study that deals specifically with the interaction between declarations developed by the university sector and declarations developed by governmental and intergovernmental institutions.

The aim of this analysis is not only to synthesize points of divergence and convergence in SHE declarations made by the university sector and governmental/intergovernmental institutions, but also to illustrate how their mutual interaction forms the basis for the discursive construction of the university's role in society in education and research policies. Thus, the following questions will be examined: Do declarations developed by the university sector differ from declarations developed by governmental or intergovernmental institutions? Is it possible to identify a number of common characteristics and themes in the SHE declarations? How have the SHE declarations developed during the last decade? It is shown that in the declarations nature is seen as also being socially produced, and that this recognition influences how sustainability and the ecological view of nature translate into specific themes in the declarations (Harvey, 1996).

\section{Methodology}

A thematic analysis makes it possible to comprehend socially constructed ecosystems as representing the 
university's 'production of nature'. Through a thematic, abductive analysis and a dialectic historicalgeographical approach it will be examined how the university 'produces nature' through its discursive practices in the SHE declarations (Harvey, 1996). In our methodological approach we have made a systematic analysis of all publicly available SHE declarations in English, German, and French from 1972 to 2010. Using previous thematic analyses of SHE declarations (Wright, 2002, 2004; Waas et al., 2009, Lozano et al., 2011) as our point of departure, a number of categories are pre-established (data construction) (Hviid et al., 2010). The discursive practises are systematically categorized, coded, and condensed according to the eight categories introduced by Wright: (1) sustainable physical operations; (2) encourage sustainable research; (3) ecological literacy; (4) moral obligation; (5) interuniversity cooperation; (6) develop interdisciplinary curriculum; (7) partnership with government, NGOs and industry; (8) public outreach (Wright, 2004; Lozano et al., 2011). After categorization, empirical data that cannot be included in existing categories have been condensed. In this way new categories have emerged. We have left out both observation statements that are considered not to be relevant in a thematic analysis and individual statements that are not systematically recognizable for which reason the establishment of a new category cannot be justified (Hviid et al., 2010). This means that the method enables us to make a thematic analysis within existing themes and at the same time examine if new themes have emerged. Wright (2004) finds that the vast majority of declarations refer to previous declarations, in which it is underlined that they should not be seen as a substitute, but as an extension, further development and supplement, e.g. Swansea (1993), Halifax (1991), IAU Kyoto (1993), and ISCN/GULF Charter (2010). This indicates both a kind of adaptation and development, and it is to be expected that recent declarations to a certain extent is framed and developed on the basis of the contents in previous declarations, while they at the same time offer new perspectives.

\section{Analysis - universities' ethical and moral responsibility according to SHE declarations}

The idea that the university is morally obliged to teach, do research and to run the university in a way that promotes sustainability is expressed in all SHE declarations. Previous analyses also point out that moral obligation is a cornerstone (Clugston, 1999; Cortese, 1999; Calder and Clugston, 2003; Wright, 2002 and 2004; Corcoran and Wals, 2004; Clarke and Kouri, 2009; Waas et al., 2009; Lozano et al., 2011) and the theme is characterized as: "Perhaps the unifying theme among all declarations and policies is the ethical and moral responsibility of universities to be leaders in promoting sustainability" (Wright, 2004).

Notwithstanding the idea that the university must take a special responsibility in promoting sustainability is relatively new and was almost unknown until the 1990's. Therefore the SHE declarations reflect a new perspective to the university's role in society (Corcoran and Wals, 2004). As is the case in Wright's (2004) and Lozano et al.'s (2011), analysis, we also find that new declarations reflect the same degree of moral obligation. Moral responsibility relates to the perception of who is responsible for what and why, for which reason the distribution of responsibility forms the moral underpinning of all declarations. Moral obligation is a complex notion that also serves as the basis for distribution of gains and burdens in negotiations on how to meet various stakeholders' interests (Andersen, 2005). According to Wright (2002, 2004) the moral aspect of the declarations is constant, but she does not further examine whether moral also relates to research and campus operations. When you study the declarations it is not clear, however, to which extent moral is considered to be important in research and campus operations, but there seems to be a tendency that the university's moral obligations first and foremost relate to education, then to research and finally to campus operations (Table 1). The preamble of the Graz Declaration (2005) is a brilliant example: "As the location of academic education, universities bear a distinctive responsibility for the students and their professional and moral quality as future leaders in society and economy. As major contributors to research they have to tackle questions which arise in connection with the transition of societies around the world towards a more sustainable development path" (Graz Declaration, 2005).

Table 1. SHE declarations and moral responsibility

\begin{tabular}{|l|c|c|c|}
\hline \multicolumn{1}{|c|}{ Declarations } & $\begin{array}{c}\text { Moral obligation related to } \\
\text { sustainable education }\end{array}$ & $\begin{array}{c}\text { Moral obligation related to } \\
\text { sustainable research }\end{array}$ & $\begin{array}{c}\text { Moral obligation related to } \\
\text { sustainable campus operation }\end{array}$ \\
\hline Stockholm 1972* & $\mathrm{X}$ & & \\
\hline Tbilisi $1977^{*}$ & $\mathrm{X}$ & $\mathrm{X}$ & \\
\hline Talloires 1990 & $\mathrm{X}$ & $\mathrm{X}$ & \\
\hline Halifax 1991 & $\mathrm{X}$ & & \\
\hline Agenda 21 1992* & $\mathrm{X}$ & $\mathrm{X}$ & $\mathrm{X}$ \\
\hline Swansea 1993 & $\mathrm{X}$ & & \\
\hline
\end{tabular}


Table 1 (cont.). SHE declarations and moral responsibility

\begin{tabular}{|c|c|c|c|}
\hline Declarations & $\begin{array}{l}\text { Moral obligation related to } \\
\text { sustainable education }\end{array}$ & $\begin{array}{l}\text { Moral obligation related to } \\
\text { sustainable research }\end{array}$ & $\begin{array}{l}\text { Moral obligation related to } \\
\text { sustainable campus operation }\end{array}$ \\
\hline IAU Kyoto 1993 & $x$ & $x$ & $x$ \\
\hline Copernicus 1994 & $x$ & & \\
\hline Thessaloniki 1997* & $x$ & & \\
\hline World Declaration on Higher Education 1998* & $x$ & & \\
\hline Charter of the Netherlands Universities 1999 & $x$ & & \\
\hline Lüneburg 2001* & $x$ & & \\
\hline Ubuntu 2002* & $\mathrm{X}$ & $\mathrm{X}$ & \\
\hline Cape Town $2002^{*}$ & $x$ & $x$ & \\
\hline Barcelona 2004 & $\mathrm{X}$ & & \\
\hline Graz 2005* & $x$ & $\mathrm{X}$ & \\
\hline Declaration on the Responsibility of Higher Education $2006^{*}$ & $\mathrm{X}$ & & \\
\hline Lucerne Declaration 2007 & $x$ & & \\
\hline ACPUCCC 2007 & $\mathrm{X}$ & $\mathrm{X}$ & $\mathrm{X}$ \\
\hline Charter for an Alliance of French Universities 2008 & $x$ & $x$ & $\mathrm{X}$ \\
\hline Sapporo 2008 & $\mathrm{X}$ & $\mathrm{X}$ & \\
\hline Tokyo Declaration 2009* & $x$ & & \\
\hline Bonn Declaration 2009* & $x$ & & \\
\hline AAU Resolution on Green Energy 2009 & $x$ & $x$ & \\
\hline Lübeck Declaration 2009* & $x$ & $\mathrm{X}$ & \\
\hline ISCN/ GULF Charter 2010 & $x$ & $x$ & $x$ \\
\hline
\end{tabular}

Note: * Made by intergovernmental/governmental institutions.

Moreover, the analysis of the universities' moral responsibility seems to imply that the reasons for the anthropogenic development (society's unsustainable development) are attributed to 'something out there', independent of the university domain, whereas the solutions mainly can be found within the university domain, hence the universities see themselves only to be morally responsible for the latter (see section on sustainable campus operation). This contrasts the dialect historical-geographical approach in which the ontological basis is that nature is also socially produced (Simonsen and Hansen, 2005). Since science and technology development is embedded in material production and consumption processes, science must also be seen as a co-producer of unintended consequences that produces a negative feed-back loop in the capital-nature relationship (Harvey, 1996). From an institutional perspective the university in this way cannot only be seen as the solution to challenges imposed by sustainability, but also as forming part of the problem (Orr, 1995). The university is seen as an institution that responds to society's needs, but the fact that the university generally is a central agent in the development of a sustainable society is criticized by Orr (1995), Bowers (1997), Calder and Clugston (1999), and Bawden (2004) that consider the university to be a paralyzed institution, incapable of integrating sustainability in its mission and activities.

Thus there seems to be a tendency that moral is distributed hierarchically. As an institution the university is seen to be able to solve society's ecological problems, but in doing so responsibility is ex- cluded from the ecological foot print made by university research and technological development (Simonsen and Hansen, 2005). In this way the ethical and moral foundation of its mission and activities contrasts scientific and theoretical reflexions of the position that nature is also socially produced (Harvey, 1996). When it comes to moral and the distribution of responsibility, contrary to our expectations, it has not been possible to identify any differences between declarations made by universities and declarations made by and between governments.

\section{Sustainable research according to SHE declarations}

In the international political debate there seems to be increasing consensus that research and technological development is of vital importance for a sustainable future. By way of example in the Declaration on Science and the Use of Scientific Knowledge adopted by UNESCO and the International Council for Science (ICSU) during the UN conference in $\mathrm{Bu}-$ dapest 1999 it is stated that: "The sciences should be at the service of humanity as a whole, and should contribute to providing everyone with a deeper understanding of nature and society, a better quality of life and a sustainable and healthy environment for present and future generations" (Declaration on Science and the Use of Scientific Knowledge, 1999).”

"Declaration on Science and the Use of Scientific Knowledge" is not a SHE declaration, for which reason it is perhaps even more interesting that sustainable development has been included as a scien- 
tific goal. As for the SHE declarations Wright (2004) and Waas et al. (2009) find that the main part of the declarations turns sustainable research into a theme. Although sustainable education is given higher priority, sustainable research still appears to be of crucial importance in the solution of society's problems (Wright, 2002). In this way, a number of SHE declarations, e.g. Kyoto (1993) $)^{1}$, Copernicus $(1994)^{2}$, Graz (2005) ${ }^{3}$, encourage universities to implement research strategies and do research that contribute to sustainable development (Corcoran et al., 2002).

University research is considered to be a cornerstone in establishing the necessary knowledge basis for political decision-making. Apart from finding thematic continuity which corresponds to the findings of Wright (2004), Waas et al. (2009) and Lozano et al. (2011), we also find that the university is explicitly and more specifically defined as an independent producer of knowledge within sustainability issues. This is particularly the case in university declarations, as in the Sapporo declaration: "the role played by universities is changing and becoming increasingly critical, since universities, being neutral and objective, are best situated to inform political and social change toward a sustainable society" (Sapporo Declaration, 2008). This quotation shows that moral responsibility cannot be looked upon as an isolated phenomenon, because it is intimately related to existing power relationships.

In spite of the great importance that is attributed to sustainable research, not much is said about what sustainable research really is:"Universities and their researchers bear the fundamental and moral responsibility to contribute with their research to sustainable development. Moreover they should consider this responsibility as a full part of the academic mission and not merely as an add on. (...) Nevertheless, within SHE this theme is little explored" (Waas et al., 2009).

In research literature this is a problem that only very few scholars have tried to address. Waas et al. (2009) define sustainable research as: "all research conducted within the institutional context of a uni-

\footnotetext{
1 “To encourage interdisciplinary and collaborative research programs related to sustainable development as part of the institution's central mission and to overcome traditional barriers between discipline's and departments" (International Association of Universities, 1993).

2 "Universities shall encourage interdisciplinary and collaborative education and research programs related to sustainable development as part of the institution's central mission; to stimulate and coordinate integrated, multidisciplinary and collaborative research projects; to disseminate the research and empirical findings widely to economic and political decision-makers" (European University Association, 1994).

3 "Call on universities to give sustainable development fundamental status in their strategy and their activities and to promote the creative development and implementation of comprehensive and integrated sustainability actions in relation to their three major functions - learning and teaching, research, internal and external social responsibility" (UNESCO, 2005).
}

versity that contributes to sustainable development" (Waas et al., 2009). According to Waas et al. (2009), sustainable research relates not only to subject oriented research within climate, energy and sustainability, but also to a new way of doing research. Therefore sustainable research must keep conventional research at a distance. Waas et al. (2009) identify six themes in the declarations that characterize sustainable research: (1) multi-/interdisciplinary; (2) participation; (3) knowledge transfer; (4) problem oriented; (5) action oriented; and (6) proactive. Though those characteristics are linked to e.g. the precautionary principle, we find that these themes do not necessarily bear a relation to sustainability, since none are different from traditional research, but must be seen as different methodological approaches to a field of studies in general science, projected to be applied within a scientific subject, namely sustainable research (Simonsen and Hansen, 2005). However, we suggest that sustainable research from a dialectic materialistic point of view must be able to transcend the six themes. Consequently we must raise the question: How does sustainable research differ from traditional research thematically, methodologically and theoretically?

\section{Experimental section - new themes explored}

As we have mentioned above we have been able to identify the following new themes since the publication of Wright's article in 2004. They are: (1) SHE declarations within specific subject areas; (2) declarations specifically aiming at reducing institutions' $\mathrm{CO}_{2}$ emissions; (3) monitoring tools; and (4) financing and grant models. Firstly we have carried through an analysis of SHE declarations made in the university sector and, secondly, we have included intergovernmental SHE declarations.

\section{Subject specific areas in SHE declarations}

We have identified series of subject specific areas in the SHE declarations. In the Barcelona Declaration (2004) it is stated that sustainability should be integrated in engineering and technical education, and the Lucerne Declaration on Geographical Education for Sustainable Development ${ }^{4}$ (2007) of course invites universities to integrate sustainability in all geographical education. So far subject specific declarations have been made only by the university sector but the relationship between intergovernmental and university declarations should also be seen in connection with the UN decade on education for sustainable development 2005-2014 (Lucerne Declaration, 2007) ${ }^{5}$.

\footnotetext{
${ }^{4}$ The International Geographical Union (IGU) and Commission on Geographical Education (CGE).

${ }^{5}$ AAU Resolution on Green Energy Research and Training (2009) is another example of a subject specific declaration (AAU Resolution, 2009).
} 


\section{Sustainable campus operations according to SHE declarations}

In recent SHE declarations universities' $\mathrm{CO}_{2}$ reduction has been introduced as a theme. However, sustainable operations is not a new theme in itself, but was already made explicit in the Talloires Declaration (1990). According to its fifth principle: "Practice Institutional Ecology" universities should show leadership in pioneering environmental responsibility. Various declarations (e.g. Swansea, $1993^{1}$; and IAU Kyoto, $1993^{2}$ ) encourage universities to examine their campus operations, but the declarations specify neither targets nor standards, nor do they precisely define what is meant by sustainable campus operations. Therefore the declarations appear to be rather vague. Thus, it is not surprising that Wright (2004) finds that sustainable operations have been given low priority in the majority of the SHE declarations (see section on moral obligations), whereas great importance is attached to $\mathrm{CO}_{2}$ reduction in society in general: "Surprisingly, the notion of developing more sustainable physical operations on the university campus does not seem a priority for the majority of declarations" (Wright, 2004).

Within the last five years, however, declarations have specifically introduced standards for $\mathrm{CO}_{2}$ reduction. We therefore find that the new theme 'universities' reduction of $\mathrm{CO}_{2}$ emission' can be identified, which is a further development of but also distinct from Wright's (2004) category of "sustainable physical operations". As it can be seen from Table 2 below the declarations have been classified into three categories. The first is declarations mentioning neither
$\mathrm{CO}_{2}$ emissions nor climate change. The second includes declarations that do mention $\mathrm{CO}_{2}$ emission and climate changes, but as society's problem only. The last category covers declarations specifically dealing with $\mathrm{CO}_{2}$ reduction both in campus operations and in society as such.

As it can be seen Talloires (1990) is the only declaration made before 2000 that specifically mentions $\mathrm{CO}_{2}$ emission. However, from 2007 and on declarations in which $\mathrm{CO}_{2}$ reduction in universities is of fundamental importance are made. ACUPCC (2007) is the most extensive declaration as it is concerned with the universities responsibility in reducing $\mathrm{CO}_{2}$ emissions and minimizing the environmental impact of their activities. One statement, among others, is that the universities should be climate neutral before $2050^{3}$, and a number of minimum requirements, standards and reporting systems are introduced, although they are not legally binding (ACUPCC, 2007). Intergovernmental declarations do not require universities to reduce $\mathrm{CO}_{2}$ emissions, only society as a whole, whereas recent university declarations stress universities' need to reduce their own emissions. Recent SHE declarations seem to favor a conceptual redefinition of sustainability to include climate change. There seems to be no significant thematic differences between SHE declarations made by university and intergovernmental institutions (Table 2). However, geographically 'environmental sustainability' is typical mostly in American declarations, whereas sustainability, as it is defined in the Brundtland report ${ }^{4}$, seems to be of greater importance in international declarations.

Table 2. SHE declarations and $\mathrm{CO}_{2}$ emissions

\begin{tabular}{|l|l|}
\hline Declarations not mentioning $\mathrm{CO}_{2}$ emissions & $\begin{array}{l}\text { Stockholm 1972*, Tbilisi 1977*, Halifax 1991, Agenda 21 1992*, Swansea 1993, IAU Kyoto 1993, Coper- } \\
\text { nicus 1994, Thessaloniki 1997*, World declaration on Higher Education 1998*, Charter of the Netherlands } \\
\text { Universities 1999, Lüneburg 2001*, Ubuntu 2002*, Cape Town 2002*, Barcelona 2004, Graz 2005*, } \\
\text { Declaration on the Responsibility of Higher Education 2006*, Charter for an Alliance of French Universi- } \\
\text { ties 2008, Tokyo 2009* }\end{array}$ \\
\hline $\begin{array}{l}\text { Declarations mentioning } \mathrm{CO}_{2} \text { emissions as a social } \\
\text { problem that might be included in curricula }\end{array}$ & Talloires 1990, Lucerne Declaration 2007, Sapporo 2008, Bonn Declaration 2009*, Lübeck Declaration 2009* \\
\hline $\begin{array}{l}\text { Declarations specifically mentioning } \mathrm{CO}_{2} \text { emissions } \\
\text { in research, education, and/or campus operations }\end{array}$ & ACUPCC 2007, AAU Resolution on Green Energy 2009, ISCN/GULF Charter 2010 \\
\hline
\end{tabular}

Note: * Made by intergovernmental/governmental institutions.

\footnotetext{
${ }^{1}$ Principle 6: "To encourage universities to review their own operations to reflect best sustainable development practices” (Swansea, 1993).

${ }^{2}$ Principle 2: "Promote sustainable consumption practices in its own operations, enhance sustainable development practices” (IAU Kyoto, 1993).

3 “(a) Within one year of signing this document, complete a comprehensive inventory of all greenhouse gas emissions (including emissions from electricity, heating, commuting, and air travel) and update the inventory every other year thereafter. We further believe that colleges and universities that exert leadership in addressing climate change will stabilize and reduce their long-term energy costs, attract excellent students and faculty, attract new sources of funding, and increase the support of alumni and local communities; (b) Adopt an energy-efficient appliance purchasing policy requiring purchase of ENERGY STAR certified products in all areas for which such ratings exist” (ACUPCC, 2007).

4 "Sustainable development seeks to meet the needs and aspirations of the present without compromising the ability to meet those of the future" (Brundtland, WCED, 1987).
} 
According to Wright (2004), the reason why sustainable campus operations were rarely introduced before 2000 (and in many recent declarations) may be huge variations from university to university that makes it difficult to set a standard of reference for physical operations. However recent developments in SHE declarations do reflect more extensive requirements as to $\mathrm{CO}_{2}$ reduction, since quantitative guidelines have been specified. Therefore, in research and education policies the role and function assigned to universities in ensuring a sustainable future seems to be changing. This development should be seen as closely related to the following theme.

\section{Mobilization of funding and development of grant structures in the SHE declarations}

We also identify a theme concerning "mobilizing financing and development of grant models" according to sustainability criteria. It is not a theme neither Wright (2002, 2004) nor Waas et al. (2009) and Lozano et al. (2011) have included in their analysis in spite of the fact that the theme can be traced back to 1990 . The first declarations encouraging to increased budgets are Talloires $(1990)^{1}$ and Halifax (1991). By way of example Halifax expresses the need for fundraising in article 37 and 83.

Halifax Declaration: "Universities must initiate the following actions (...): 37. Funding scholarships in sustainable development; (...): 83. Encouraging government to assign a percentage of external aid funding for basic education and training in sustainable development" (Halifax Declaration, 1991).

We have made a systematic analysis of declarations to see: (a) if the declarations introduce mobilization of funding as a theme; (b) if so, if external funding is recommended; (c) if increased internal financing is also recommended, and d) if it is also recommended to change grant structures integrating $\mathrm{ESD}^{2}$ as a criterion (Table 3).

The categorization of SHE declarations demonstrates that nearly no declaration recommends universities to increase funding to sustainable campus operations. The invitation to increased funding applies primarily to education and to some extent research. Quantitatively the proportion of declarations mentioning financing is constant over time, but qualitatively the analysis seems to indicate that recent declarations are more extensive and direct in their way of recommending governments and states to mobilize necessary funding (AAU Resolution, 2009). Precisely funding is an issue that separates intergovernmental declarations from university declarations, since the latter more directly recommends fund raising (Tokyo Declaration, 2009).

Table 3. SHE declarations, funding and grant models

\begin{tabular}{|l|l|}
\hline $\begin{array}{l}\text { SHE declarations not mentioning funding of } \\
\text { sustainability in research and education }\end{array}$ & $\begin{array}{l}\text { Stockholm 1972*, Tbilisi 1977*, IAU Kyoto 1993, Copernicus 1994, World Declaration on Higher Education } \\
1998^{*}, \text { Charter of the Netherlands Association of Universites (1999), Lüneburg 2001*, Ubuntu 2002*, Graz } \\
2005^{*}, \text { Declaration on the Responsibility of Higher Education 2006*, ACUPCC 2007, Lucerne 2007, Charter for } \\
\text { an Alliance of French Universities (2008), Sapporo (2008), Tokyo 2009*, Lübeck 2009*, ISCN/GULF 2010 }\end{array}$ \\
\hline $\begin{array}{l}\text { SHE declarations recommending increased } \\
\text { external funding of research and education }\end{array}$ & Rio, Agenda 21, 1992*, Thessaloniki 1997*, Cape Town 2002*, AAU Resolution 2009 \\
\hline $\begin{array}{l}\text { SHE declarations recommending increased } \\
\text { internal and/or external funding of research and } \\
\text { education }\end{array}$ & Talloires 1990, Halifax 1991, Swansea 1993, Barcelona 2004 \\
\hline $\begin{array}{l}\text { SHE declarations also inviting to change grant } \\
\text { structures through the integration of ESD }\end{array}$ & Bonn 2009* \\
\hline
\end{tabular}

Note: * Made by governmental/intergovernmental institutions.

In this way the Association of American Universities' (AAU) Resolution on Green Energy Research and Training (2009) is the most concrete and direct declaration when it comes to increased funding within research and education. The declaration is a recommendation to the American Congress to appropriate 160 billion US dollars for research and education in sustainable energy (AAU Resolution, 2009). The Bonn Declaration (2009), on the other hand, is intergovernmental, and the most extensive, since it is an example that not only funding, but also grant structures have

\footnotetext{
1 “Thus, university leaders must initiate and support mobilization of internal and external resources so that their institutions respond to this urgent challenge” (Association of University Leaders for a Sustainable Future, 1990).
}

been included in the SHE declarations' agenda. In this way the declaration aims at both mobilizing sufficient resources for ESD funding that is especially integrated as part of the countries' education policies and grant systems, and forming the basis for prioritizing funds and donations (Bonn Declaration, 2009).

It should be noted, however, that declarations not directly recommending increased fund raising activities, in some cases incorporate funding indirectly. The Graz Declaration (2005) does not mention financing, but since the declaration aims at influencing the Bologna process, it does include

\footnotetext{
${ }^{2}$ Education for Sustainable Development.
} 
financing implicitly. Thus some declarations do not turn financing into a theme; they indirectly attempt to influence the receiver (governments) to increase appropriations. When we take into consideration that the theme appeared only in 2009, it remains to be seen whether future declarations will also recommend further development of grant models and if intergovernmental declarations will take the lead.

\section{Monitoring tools according to the SHE declarations}

Finally we find that monitoring tools is a new theme that has gradually gained a foothold on the agenda in the past decade. However, no declaration offers concrete tools to reduce the environmental impact of university activities: "However, no declaration offers practical actions to take in order to ensure more sustainable physical operations" (Wright, 2002). Declarations made before the turn of the millennium do however list tools such as questionnaires and best practices, but not monitoring tools to be defined as tools that in the first place enable universities to systematically compare and assess achievements in and across categories and in the second place enable "interuniversity" comparisons.

We have analyzed all declarations systematically to see: (a) if monitoring tools are mentioned at all; (b) if they invite universities to develop monitoring tools within research, education and/or campus operations; and (c) if declarations require that specific monitoring tools should be used to report on the implementation of declarations (Table 4).

Table 4. SHE declarations, standards and monitoring tools

\begin{tabular}{|l|l|}
\hline $\begin{array}{l}\text { SHE declarations not recommending monitoring } \\
\text { tools are developed/used }\end{array}$ & $\begin{array}{l}\text { Stockholm 1972*, Tbilisi 1977*, Talloires 1990, Halifax 1991, Rio Agenda 21 1992*, Swansea 1993, IAU Kyoto } \\
\text { 1993, Copernicus 1994, World Declaration 1998*, Charter of the Netherlands Association of Universites 1999, } \\
\text { Ubuntu 2002, Cape Town 2002*, Barcelona 2004, Graz 2005*, Declaration on the Responsibility of Higher } \\
\text { Education 2006*, Lucerne 2007, Charter for an Alliance of French Universities in Fostering Sustainable Devel- } \\
\text { opment (2008), Sapporo (2008), AAU Resolution on Green Energy Research and Training (2009), Lübeck } \\
\text { Declaration 2009* }\end{array}$ \\
\hline $\begin{array}{l}\text { SHE declarations recommending that monitor- } \\
\text { ing tools are developed }\end{array}$ & Thessaloniki 1997*, Lüneburg 2001*, Tokyo 2009*, Bonn Declaration 2009* \\
\hline $\begin{array}{l}\text { SHE declarations recommending/demanding that } \\
\text { standardized monitoring tools are used in reports }\end{array}$ & ACUPCC 2007, ISCN/GULF 2010 \\
\hline
\end{tabular}

Note: * Made by governmental/intergovernmental institutions.

The Thessaloniki Declaration (1997) is the first to mention the need for developing tools to evaluate study programs. It does not, however, add any further specifications on how this is to be done as is the case in the Lüneburg Declaration $(2001)^{1}$. No other declaration takes into consideration problems concerning the implementation of previous declarations, and no other declaration recommends in such concrete terms that monitoring and management tools should be developed. Furthermore the Lüneburg declaration (2001) is the only declaration that lays down instructions on what monitoring tools should be able to measure within education and campus operations. Also the Bonn and Tokyo Declarations encourage universities to develop monitoring tools, but only within education: "develop the global monitoring and evaluation system to evaluate ESD" (Tokyo Declaration, 2009). It is thus worth noticing that only two out of 26 SHE declarations (ACUPCC and

\footnotetext{
${ }^{1}$ Article 7c: "Produce an action-oriented Toolkit for universities, managers, administrators, faculty and students designed to move from commitment to concrete action. The Toolkit would include: implementation strategies for colleges and universities depending on size, type, demographic characteristics, etc.; strategies for reform in particular areas of university activity, including teaching, research, operations and outreach, or for comprehensive change across all universities activities; an inventory of available resources; an inventory of best practices and compilation of case studies” (Lüneburg Declaration, 2001).
}

ISCN/GULF) demand or recommend universities to use monitoring tools when they report on implementation (ACUPCC, 2007). In this way the majority of declarations set goals without ensuring that tools exist to evaluate the implementation of declarations. Four declarations encourage the development of monitoring tools to evaluate ESD, and only Lüneburg (2001) invites universities to develop tools to monitor campus operations. No declaration invites universities to develop tools, instruments or indicators to monitor sustainable research. Finally the table illustrates that SHE declarations made by the university sector are the most extensive in recommending the development and use of monitoring tools.

\section{Conclusion}

Overall we find conformity with Wright's themes, in spite of the fact that we have increased the number of declarations in our analysis. Thus, the interaction between intergovernmental and university declarations produces surprisingly identical themes, only with minor distinctions. However, we have identified four new themes: (1) SHE declarations within specific subject areas; (2) declarations specifically aiming at reducing institutions' $\mathrm{CO}_{2}$ emissions; (3) monitoring tools; and (4) financing and grant models which have increasingly been made subject to debate in the declarations. Interaction between university 
and intergovernmental declarations reveals that the reason for the anthropogenic development (society's unsustainable development) should be found "out there" distinct from the universities' domain, while solutions on sustainability issues are explicitly within the universities' domain. This, in turn, contradicts methodological reflections on the degree in which previous research and technology developments have contributed to the ecological crisis.

As to the mobilization of funding, this study indicates that new declarations are more comprehensive and directly urging governments to rise the funding needed. Intergovernmental and university declarations seem to differ, since the latter is the most concrete and direct in urging the need for funding. This may be the reason why declarations made by universities are the most direct in encouraging universities to bring monitory tools into use. In this way the four new themes illustrate how the valuation of nature is under reconfiguration in higher education institutions. Finally, the study reveals that sustainable research is characterized by several themes projected from traditional research to a specific subject area, namely sustainable research. We suggest that sustainable research from a dialectic materialistic point of view must be able to transcend the six themes, methodologically, theoretically, and empirically. More research is needed to explore different research practices' relation to nature, and how sustainable research, methodologically, theoretically, and empirically are distinct from traditional research.

\section{References}

1. AAU Resolution on Green Energy Research and Training (2009). Association of American Universities.

2. Alshuwaikhat, H., Abubakar, I. (2008). "An integrated approach to achieving campus sustainability: assessment of the current campus environmental management practices”, Journal of Cleaner Production, 16, pp. 1777-1785.

3. American College and University President's Climate Commitment (2007). ACUPCC.

4. Andersen, H. (2005). "Samfundsteori, moral og det civile samfund”, Ed. Andersen H. \& Kaspersen, 3rd edition, Copenhagen, pp. 530-547.

5. Barcelona Declaration (2004). EESD.

6. Bekessy, S., Samson, K., Clarkson R. (2007). "The failure of non-binding declarations to achieve university sustainability - a need for accountability”, International Journal of Sustainability in Higher Education, Vol. 8, No. 3, 30 p.

7. Bonn Declaration (2009). World Conference on Education for Sustainable Development, UNESCO.

8. Bowers, C.A. (1997). “Challenges in Educating for Ecologically Sustainable Communities”, Educational Philosophy and Theory, Vol. 33, No 2, pp. 257-265.

9. Bawden R. (2004). "Sustainability as emergence: The need for engaged discourse” in Corcoran, Peter Blaze and Wals Arjen J. (2004) "Higher Education and the Challenge of Sustainability: Problematics, Promise, and Practice”, Kluwer Academic Publishers, Hingham, MA, USA.

10. Calder, W., Clugston, R. (2003). "Progress toward Sustainability in Higher Education”, Environmental Law Reporter, 33, pp. 10003-10023.

11. Cape Town Declaration on Research for Sustainable Development (2002). Association of the Caribbean and the Pacific group of States (ACP).

12. Charter for an Alliance of French Universities (2008).

13. Charter of the Netherlands Association of Universities of Applied Science (1999).

14. Clarke, A., Kouri, R. (2009). "Choosing an appropriate university or college environmental management system”, Journal of Cleaner Production, 17, pp. 971-984.

15. Clugston, R., Calder, W. (1999). “Critical Dimensions of Sustainability in Higher Education”, In Sustainability and University Life (Ed.), Walter Leal Filho, Lang Peter.

16. Copernicus University Charter for Sustainable Development (1994). European University Association.

17. Corcoran, P., Wals, A. (2004). "Higher education and the challenge of sustainability, problematics, promise, and practice”, Dordrecht: Kluwer.

18. Corcoran, P., Calder, W., Clugston R. (2002). “Introduction: higher education for sustainable development”, Higher Education Policy, 15, pp. 99-103.

19. Cortese, A. (1999). "Education for Sustainability, the University as a model of Sustainability", Second Nature Education for Sustainability.

20. Declaration on Science and the Use of Scientific Knowledge (1999). UNESCO.

21. Declaration on the Responsibility of Higher Education for a Democratic Culture - Citizenship, Human Rights and Sustainability (2006). UNESCO.

22. Graz Declaration (2005). UNESCO.

23. Grindsted, T. (2011). "Sustainable Universities - From Sustainability in Higher Education Declarations to national law”, Journal of Environmental Economics, Issue 2, pp. 29-36.

24. Halifax Declaration (1991). Association of Universities and Colleges in Canada.

25. Harpe, B., and Thomas, I. (2009). "Curriculum Change in Universities: Conditions that Facilitate Education for Sustainable Development”, Journal of Education for Sustainable Development, 2009, Volume 3 (1), pp. 3-75. 
26. Harvey, D (1996). “Justice, Nature \& the Geography of Difference”, Blackwell Publishers Ltd, Massachusetts, Cambridge.

27. Hviid Jakobsen, M., Rasmussen, K., Nedergaard, P. (2010). “Videnskabsteori - i statskundskab, sociologi og forvaltning”, Hans Reitzels Forlag, København.

28. IAU Kyoto Declaration (1993). International Association of Universities.

29. ISCN/Gulf Sustainable Campus Charter (2010). ISCN/Gulf.

30. Lozano, R. et al. (2011). "Declarations for sustainability in higher education: becoming better leaders, through addressing the university system”, Journal of Cleaner Production, pp. 1-10.

31. Lübeck Declaration: Universitites for Sustainable Development (2009). UNESCO.

32. Lucerne Declaration on Geographical Education for Sustainable Development (2007). The International Geographical Union (IGU), Commission on Geographical Education (CGE).

33. Lüneburg Decleration (2001). UNESCO.

34. Mcmillin, J., and Dyball, R. (2009). "Developing a Whole-of-University Approach to Educating for Sustainability: Linking Curriculum, Research and Sustainable Campus Operations”, Journal of Education for Sustainable Development, pp. 3-55.

35. Orr, D. (1995). “Educating for the Environment: Higher Education's Challenge of the Next Century”, Journal of Environmental Education, 1996 - Routledge.

36. Promoting Education, Public Awareness and Training (1992). Agenda 21, Kap. 36. UNSCD.

37. Sapporo Sustainability Declaration (2008). G8 University Summit.

38. Simonsen, K. \& Hansen, F. (2004). Geografiens Videnskabsteori - en introducerende diskussion, Roskilde Universitetsforlag.

39. Stockholm Declaration (1972). UNESCO.

40. Swansea Declaration (1993). Association of Commonwealth Universities.

41. Talloires Declaration (1990). University Leaders for a Sustainable Future, ULSF.

42. Tbilisi Declaration (1977). UNESCO.

43. Thessaloniki Declaration (1997). UNESCO.

44. Tokyo Declaration of Hope (2009). UNESCO.

45. Ubuntu Declaration on Education and Science and Technology for Sustainable Development (2002). UNESCO.

46. UNSCD (1992).”Promoting Education, Public awareness and Training”, Agenda 21, chapter 36.

47. Waas, T., Verbruggen, A. Wright, T. (2009). "University research for sustainable development: definition and characteristics explored”, Journal of Cleaner Production, pp. 1-8.

48. WCED (1987). Brundtland report, 1987.

49. World Declaration on Higher Education for the Twenty-First Century: Vision and Change and Framework for Priority Action for Change and Development in Higher Education (1998). UNESCO.

50. Wright, T. (2002). "Definitions and Frameworks for Environmental Sustainability in Higher Education”, International Journal of Sustainability in Higher Education, Vol. 3 (3), pp. 203-220.

51. Wright, T. (2004). "The evolution of sustainability declarations in higher education”, In Higher Education and the Challenge of Sustainability’ (Ed) Corcoran, P., Wals A: Kluwer Academic, Dordrecht, Netherlands, pp. 7-14.

52. Wright, T., and Pullen, S. (2007). "Examining the Literature: A Bibliometric Study of ESD Journal Articles in the Education Resources Information Center Database”, Journal of Education for Sustainable Development, Vol. 1 (1), pp. 77-90.

53. Zilahy, G. (2009). "Roles of academia in regional sustainability initiatives: outreach for a more sustainable future”, Journal of Cleaner Production, 17, pp. 1053-1056. 